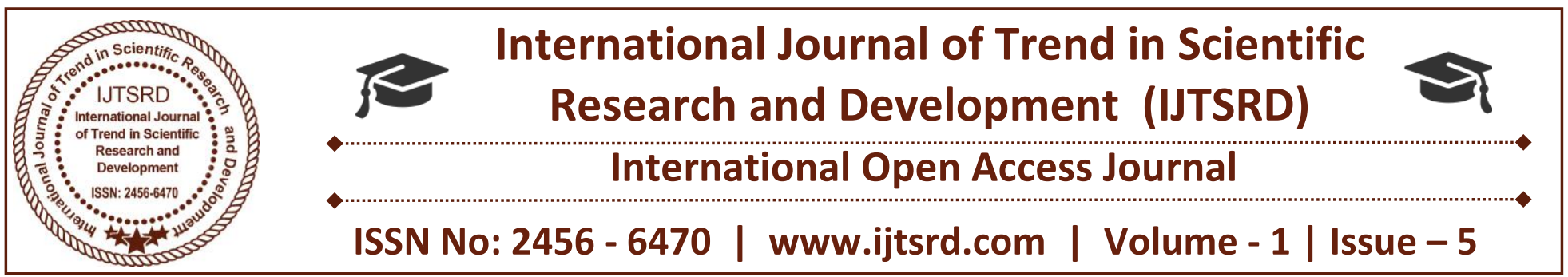

\title{
Use of Demolished Concrete in Pavement Construction
}

\author{
Munesh Kumar \\ MTech Scholar, Department of Civil Engineering, \\ Om Institutes of Technology \& Management, \\ Juglan Hisar, Haryana, India
}

\author{
Sumesh Jain \\ Asst. Professor, Department of Civil Engineering, \\ Om Institutes of Technology \& Management, \\ Juglan Hisar, Haryana, India
}

\begin{abstract}
Recycled aggregates consist of crushed, graded inorganic particles processed from the material that have been used in the constructions and demolition debris. The target of the present thesis work is to determine the strength characteristic of recycled aggregates for the application in concrete pavement construction. The scope of the thesis is to determine and compare the compressive strength, flexural strength and sulphate resistance of concrete by using different percentages of recycled aggregates. The investigation was carried out by using workability test, compressive strength test, flexural strength test and sulphate resistance test. A total of five mixes with replacement of coarse aggregates with $0 \%, 10 \%$, $20 \%, 30 \%$ and $40 \%$ recycled coarse aggregates were studied. The water cement ratio was kept constant at 0.38 . It was observed that workability of concrete was decreased with the increase in recycled aggregates in concrete. For the strength characteristics, the results showed that the strengths of recycled aggregate concrete were comparable to the strengths of natural aggregates concrete.
\end{abstract}

\section{INTRODUCTION}

In the era of construction, concrete has been the leading building material since it was discovered and found viable for future due to its durability, easy maintenance, wide range of properties and adaptability to any shape and size. Concrete is the composite mix of cement, aggregates, sand and water. Concrete gets hardened like stone on mixing water with cement and aggregates. Concrete have two types of ingredients namely active and inactive. The active group consists of water and cement. The inactive part consists of sand and coarse aggregates. Concrete have high compressive strength and low tensile strength. To overcome this shortcoming, steel reinforcements are used along with the concrete. This type of concrete is called reinforced cement concrete (RCC).

Concrete structures that are designed to have service lives of at least 50 years have to be demolished after 20 or 30 years because of deterioration caused by many agents. Old buildings require maintenance for better and higher economics gains. The rate of demolition has increased and there is a shortage in dumping space and also increase in cost of dumping. Instead of dumping this demolished concrete, use of demolished as recycled concrete would not only reduce the cost but also will conserve the non renewable energy sources. The use of demolished concrete will further result in reduction in use of natural aggregates. The usage of natural aggregates is causing damage to natural resources resulting in imbalance in environment. Recycled aggregates consist of crushed, graded inorganic particles obtained from the materials that have been used in constructions. Recycled aggregates are generally obtained from buildings, roads and bridges which are demolished due to completion of life, wars and earthquake. 


\section{MATERIAL METHODOLOGY}

AND

DESIGN

Workability

Workability of concrete was checked by using slump test and compaction factor test.

\section{Size of the Test Specimens}

Moulds of cast iron were used to cast test samples, in shape of cube. Dimensions of cube were $150 \mathrm{~mm} \times 150 \mathrm{~mm} \times 150 \mathrm{~mm}$

\section{Casting of Specimens}

Cubic moulds were well cleaned before pouring concrete in them. Mould oil was applied to inner sides of mould to avoid the sticking of concrete to sides of mould. Side plates were tightly assembled after application of mould oil between the joints. Concrete was poured in them and tamped with tamping rod.

\section{Compacting of Concrete Samples}

Compacting of concrete was done by table vibrator. Vibrating was done till desired compaction was reached.

\section{Capping of Samples}

Even after vibrating the samples, the top of the cubes were not plain. Capping was done to make this side plain. The plainness of top side was checked by means of straight edge and filler gauge. Caps were made thin as practicable they could be. It was taken into consideration that capping did not cause fracture while testing the samples.

\section{Testing For Compression Strength}

\section{Testing Machine}

Compressive strength testing machine was used to test the samples for compressive strength. The test samples were tested at the age of 7,28, 56 and 90 days. The ages of samples were considered from the time water was added to dry materials. Three samples for each batch were prepared and their average value was taken for final compressive strength.

\section{EXPERIMENTAL PROGRAMME}

Mix design is done to select the mix material and their required proportions. There are a lot of methods to determine the mix design. The methods used in India are in compliance with Bureau of Indian Standards (BIS). The motive of mix design is to determine the proportion in which concrete ingredients like cement, water, fine aggregates and coarse aggregates should be mixed to provide specified strength, workability, durability and other specified requirements as listed in standards such as IS: 456-2000. The designed concrete mix must define the material and strength, workability and durability to be attained. Concrete mix design guidelines are given in IS: 10262-1982. In the study, 5 batches of mixes were prepared. These batches were designated as $\mathrm{m} 0, \mathrm{~m} 1, \mathrm{~m} 2, \mathrm{~m} 3$ and $\mathrm{m} 4$. Batch $\mathrm{m} 0$ was taken as control mix. The natural coarse aggregate was replaced by recycled aggregate in proportion of $0 \%, 10 \%, 20 \%, 30 \%$ and $40 \%$ in $\mathrm{m} 0$, $\mathrm{m} 1, \mathrm{~m} 2, \mathrm{~m} 3$, and $\mathrm{m} 4$ respectively as given in table 4.1. Content of sand, cement and water were kept constant in every batch. In the study properties of concrete such as compressive strength, flexural strength and sulphate resistance of concrete were determined.

\section{Proportions of Natural and Recycled Aggregates in Batches}

\begin{tabular}{|c|c|c|}
\hline $\begin{array}{c}\text { Type of Mix } \\
\text { Used }\end{array}$ & $\begin{array}{c}\text { Recycled } \\
\text { Aggregate (\%) }\end{array}$ & $\begin{array}{c}\text { Natural } \\
\text { Aggregate (\%) }\end{array}$ \\
\hline $\mathrm{m} 0$ & 0 & 100 \\
\hline $\mathrm{m} 1$ & 10 & 90 \\
\hline $\mathrm{m} 2$ & 20 & 80 \\
\hline $\mathrm{m} 3$ & 30 & 70 \\
\hline $\mathrm{m} 4$ & 40 & 60 \\
\hline
\end{tabular}

Physical Properties of Cement of Grade 43

\begin{tabular}{|l|l|l|l|l|}
\hline S.No. & Properties & $\begin{array}{l}\text { Apparat } \\
\text { us used }\end{array}$ & $\begin{array}{l}\text { Observ } \\
\text { ed } \\
\text { Values }\end{array}$ & $\begin{array}{l}\text { Values } \\
\text { Specifie } \\
\text { d by } \\
\text { IS:8112- } \\
1989\end{array}$ \\
\hline 1. & $\begin{array}{l}\text { Fineness } \\
\text { Percentage }\end{array}$ & $\begin{array}{l}90 \mu \mathrm{m} \text { I.S } \\
\text { Sieve }\end{array}$ & 4 & $\begin{array}{l}\text { Not } \\
\text { more } \\
\text { than } 10\end{array}$ \\
\hline 2. & $\begin{array}{l}\text { Soundness( } \\
\text { mm) }\end{array}$ & $\begin{array}{l}\text { Le } \\
\text { Chatelier } \\
\text { Method }\end{array}$ & 1.0 & $\begin{array}{l}\text { Not } \\
\text { more } \\
\text { than } 10\end{array}$ \\
\hline 3. & $\begin{array}{l}\text { Normal } \\
\text { consistency }\end{array}$ & $\begin{array}{l}\text { Vicat } \\
\text { apparatus }\end{array}$ & 30 & $\ldots \ldots \ldots .$. \\
\hline 4. & $\begin{array}{l}\text { Specific } \\
\text { gravity }\end{array}$ & $\begin{array}{l}\text { Le } \\
\text { Chaterlier } \\
\text { "s flask }\end{array}$ & 3.76 & $\ldots . . . . . .$. \\
$\ldots$
\end{tabular}


International Journal of Trend in Scientific Research and Development (IJTSRD) ISSN: 2456-6470

Sieve Analysis of Fine Aggregates

\section{Weight of sample $=1000 \mathrm{gm}$}

\begin{tabular}{|l|l|l|l|l|}
\hline $\begin{array}{l}\text { IS } \\
\text { Sieve } \\
\begin{array}{l}\text { Size( } \\
\text { mm) }\end{array}\end{array}$ & $\begin{array}{l}\text { Weight } \\
\text { Retained } \\
\text { (gm) }\end{array}$ & $\begin{array}{l}\text { Cumulat } \\
\text { ive } \\
\text { Weight } \\
\text { Retained } \\
\text { (gm) }\end{array}$ & $\begin{array}{l}\text { Cumulat } \\
\text { ive } \\
\text { \%Age of } \\
\text { Weight } \\
\text { Retained } \\
\text { (gm) }\end{array}$ & $\begin{array}{l}\text { Percen } \\
\text { tage } \\
\text { Passing }\end{array}$ \\
\hline 4.75 & 156 & 156 & 15.6 & 84.4 \\
\hline 2.36 & 57 & 213 & 21.3 & 78.7 \\
\hline 1.18 & 113 & 326 & 32.6 & 67.4 \\
\hline 0.6 & 111 & 437 & 43.7 & 56.3 \\
\hline 0.3 & 376 & 813 & 81.3 & 18.7 \\
\hline 0.15 & 145 & 958 & 95.8 & 4.2 \\
\hline 0.075 & 30 & 988 & 98.8 & 1.2 \\
\hline$\sum F=389.3$ & & & \\
\hline
\end{tabular}

$\sum \mathbf{F}=\mathbf{3 8 9 . 3}$

Fineness Modulus (F.M) $=3.89$

Physical Properties of Recycled Aggregates

\begin{tabular}{|c|c|}
\hline Property & Observed Values \\
\hline $\begin{array}{c}\text { Bulk Density } \\
(\text { Loose }),\left(\mathrm{kg} / \mathrm{m}^{3}\right)\end{array}$ & 1132 \\
\hline $\begin{array}{c}\text { Bulk } \\
\text { Density }(\text { compacted }) \\
\left(\mathbf{k g} / \mathbf{m}^{\mathbf{3}}\right)\end{array}$ & 1328 \\
\hline Specific gravity & 2.52 \\
\hline Water absorption (\%) & 1.9 \\
\hline
\end{tabular}

\section{CONCLUSIONS}

The research on usage of RCA in construction of pavement is very important because material waste is gradually increasing with the increase in urban development and increase in population. Recycled aggregates are easily available while natural aggregates need mining and their cost is much higher than the cost of natural aggregates. Recycled aggregates are cheaper than the virgin aggregates, so builders can easily afford these for construction purpose if their strength is equal or comparable to natural aggregates.

The study examines the properties of RCA when used with natural coarse aggregates. A lot of studies have been carried out on use of RCA concrete in construction. But in case of highway construction some more investigation is required. The main objective of the study was to investigate whether RCA can be used as material aggregates for concrete pavement construction. Compressive strength, flexural strength and sulfate resistance of RCA concrete is examined, where it was observed that mixing of RCA cause increased water absorption. To avoid this, super plasticizer is used to reduce the cement consumption. Concrete mix of M40 was designed as per properties of aggregates. The results of this study showed that RCA concrete gave comparable strength to conventional concrete. This indicated that RCA concrete can be viable source for construction of pavements. From the results, it is also found that workability of concrete is decreased due to higher water absorption. Whenever recycled aggregate is applied, water content is monitored carefully in concrete mix as water absorption is increased due to presence of porous mortar. In this study, super plasticizer ( $0.6 \%$ of cement) is used to overcome this problem.

Following conclusions can be drawn from results and discussion of results from the study:

1. The compressive strength of all mixes exceeded at the age of 28 days. Compressive strength of control mix i.e. of $\mathrm{m} 0$ is $50.05 \mathrm{MPa}$ which is greater than the target strength of 48.25 for M40 concrete. Compressive strength of $\mathrm{m} 1$ is slightly increased to 50.36. So the compressive strength increases by $0.5 \%$. For $\mathrm{m} 2$, compressive strength is increased to $50.20 \mathrm{MPa}$, it also showed an increase in compressive strength by $0.3 \%$. Compressive strength of $\mathrm{m} 3$ is decreased to 49.11 $\mathrm{MPa}$ that showed a decrease in compressive strength by $1.9 \%$. But in case of $\mathrm{m} 4$, there is sudden increase in compressive strength that raises the compressive strength to $52.36 \mathrm{MPa}$. Compressive strength is increased by $4.5 \%$. So the results of test show that compressive strength does not follow a regular trend from $\mathrm{m} 0$ to $\mathrm{m} 4$. But from the results it is also concluded that compressive strength never went below the target strength for 28 days. This indicates that RCA can be used as replacement aggregates for compressive strength.

2. Flexural strength also followed the same pattern as of compressive strength. Flexural strength of control mix is $5.32 \mathrm{MPa}$ at age of 28 days. Flexural strength of mix $\mathrm{m} 1$ increased to $5.60 \mathrm{MPa}$. It shows that the increase in flexural strength is $5 \%$ for $\mathrm{m} 1$. For $\mathrm{m} 2$ flexural strength at age of 28 days is $5.40 \mathrm{MPa}$, which shows an increase in flexural strength by $1.5 \%$. Flexural strength of mix $\mathrm{m} 3$ is 5.38 and the flexural strength increased by $1 \%$. 
For the mix m4, flexural strength is $5.40 \mathrm{MPa}$. It shows that the flexural strength increased by 1.5 $\%$ at the age of 28 days. From the results and discussion of the results it is found that the flexural strength of RCA concrete is comparable to the natural aggregate concrete which is a positive point. So the RCA concrete can be used for flexural strength by adjusting W/C ratio.

3. Use of $5 \%$ of $\mathrm{MgSO}_{4}$ solution caused the reduction in compressive strength. The compressive strength of RCA mixed concrete reduced upto $7 \%$. Effect of sulphate solution increased when quantity of demolished concrete aggregate increased. This study showed that the strength of $\mathrm{m} 4$ at 56 days was most affected. So with increase in sulphate caused reduction in compressive strength of concrete.

4. It was found that the RCA concrete have relatively lower bulk density, specific gravity and high water absorption as compared to natural concrete. This was due to the presence of mortar in present on recycled coarse aggregates.

5. In this study, trial castings were done to arrive at water content and desired workability. So it was advisable to carry out trial castings with demolished concrete aggregate proposed to be used in order to arrive at the water content and its proportion to match the workability levels and strengths requirements respectively.

6. From this study it was observed that the demolished concrete was viable source for construction of concrete pavements. Economical and environmental pressures justify suitability of RCA concrete as alternative to the natural concrete. Where there is non-availability of natural aggregate from new rocks RCA can be a good or viable replacement option for natural coarse aggregate in pavement construction.

From above conclusions it can be said that it is ecofriendly and creative to use demolished concrete in construction of concrete pavements.

\section{REFERENCES}

1. Abou-Zeid, M.N., Shenouda, M.N., McCabe, S.L., and El-Tawil, F.A. (2005). "Reincarnation of Concrete," Concrete International, V. 27, No.2, February 2005, pp. 53-59.

2. Ajdukiewicz, A., and Kliszczewica, A. (2002). "Influence of Recycled Aggregates on Mechanical Properties of HS/HPS," Cement and Concrete Composites, V. 24, No. 2, 2002, pp. 269-279.
3. Bairagi, N. K., Vidyadhara, H. S., and Ravande, K. (1990). "Mix Design Procedure for Recycled Aggregate Concrete," Construction and Building Materials, V. 4, No. 4, December 1990, pp. 188193.

4. Buyle-Bodin, F., "Influence of industrially produced recycled aggregates on flow of properties of concrete." Materials and structures/ Mate'riaux et. Construction, Vol. no. 35, September-October 2002,pp 504-509.

5. Chen, H.J., Yen, T., and Chen, K.H. (2003). "Use of Building Rubbles as Recycled Aggregate,"Cement and Concrete Research, V.33, No.1, pp. 125-132.

6. FHWA. (2004). "Transportation Applications Of Recycled Concrete Aggregate: FHWA State of the Practice National Review September 2004," U.S. Department of Transportation, Federal Highways Administration, Washington, DC.

7. GTAA. (2007). "Reducing, Reusing and Recycling Terminal 2," Toronto Pearson Today: Terminal 2, Terminal 2 Commemorative Issue, Greater Toronto Airports Authority, Toronto, ON.

8. Hansen, T.C., and Hedegard, S.E. (1984). "Properties of Recycled Aggregate Concretes as Affected by Admixtures in Original Concretes," ACI Journal, January-February 1984, pp. 21-26.

9. Harrington, J. (2004). "States Achieve Recycling Success," Roads and Bridges, V.42, No.7.

10. Hendricks, Ch. F., "Use of Recycled materials in constructions", Materials and structures/ Mate'riaux et. Construction, Vol. no. 36, November 2003,pp 604-608.

11. IS: 456-2000, "Indian Standard Code of practice for plain and reinforced concrete", (second revision), Bureau of Indian Standard, New Delhi.

12. IS: 383-1963, "Indian Standard Specifications for Coarse and Fine Aggregate from Natural Sources for Concrete", Bureau of Indian Standard, New Delhi.

13. IS: 516-1959, "Methods of Tests for Strength of Concrete", Bureau of Indian Standard, New Delhi.

14. IS: 10262-1982, "Recommended Guidelines for Concrete Mix design", Bureau of Indian Standard, New Delhi.

15. IS: 2386(Part-1)-1963, "Methods of Test for Aggregate for Concrete (Part-1 Particle Size and Shape)", Bureau of Indian Standard, New Delhi.

16. IS: 8112-1989, "Specification for 43 Grade Ordinary Portland Cement", Bureau of Indian Standard, New Delhi. 